\title{
High School Students' Beliefs about the Role and Goal of Learning Pronunciation in EFL Classrooms in Binh Phuoc Province
}

\author{
Le Thanh Huyen* \\ Ho Chi Minh City University of Technology (HUTECH), Vietnam
}

*Corresponding Author: Le Thanh Huyen, Ho Chi Minh City University of Technology (HUTECH), Vietnam

\begin{abstract}
Pronunciation is an essential part in English language learning. In EFL classrooms, however, pronunciation seems to be neglected which may cause unintelligibility in oral communication. Although it is very significant to determine learners' beliefs about pronunciation, research on this field has been limited so far. Therefore, the present study aimed to investigate Binh Phuoc high school students' beliefs about the role and goal of learning pronunciation in EFL classrooms. The quantitative approach was employed with the participation of 249 students in three grades of 10, 11, and 12 from four high schools in Binh Phuoc province. The data collected from the questionnaires were processed by SPSS (24.0). The findings revealed thatmost of the students in this study valued the importance of pronunciation for oral communicative competence and acknowledged the intelligibility in pronunciation as the appropriate goal of learning pronunciation. Ultimately, it is recommended that more studies on examining teachers' beliefs about pronunciation, a comparison between students' and teachers' views should be made. Furthermore, surveys on the current practices of learning and teaching pronunciation in EFL classrooms should be conducted in which different instruments should be used for data collection.
\end{abstract}

Keywords: beliefs, goals, pronunciation, roles, Vietnamese EFL context.

\section{INTRODUCTION}

Although the critical role of good pronunciation in oral communication has been proved, identified and affirmed among educational local stakeholders, and demonstrated through several policies and decisions by Vietnamese MOET, the quality of English language teaching and learning has been assessed to be at a low level. In fact, students may be good at grammar; however, they cannot communicate effectively.

There have been many factors that both positively and negatively affect pronunciation learning. Beliefs are considered the deciding factors because learners who have negative beliefs towards pronunciation will face difficulties in their foreign language learning process and vice versa (Kenworthy, 1987). Despite the significance of determining learners' beliefs about pronunciation learning process, the number of research on language learners' beliefs is limited (Baker, 2014; Buss, 2015).

Regarding EFL in contemporary, a considerable amount of literature concerning pronunciation has been written by Vietnamese researchers; however, these studies have not focused on learners' beliefs towards pronunciation (Truong, 2018). The objective of this study, therefore, is to investigate Binh Phuoc high school students' beliefs about the role and goal of pronunciation in EFL classrooms.

\section{LITERATURE REVIEW}

\subsection{The Importance of Pronunciation in Oral Communication}

Burns (2006) points out that speakers can make spoken communication effective with clear pronunciation, although they make some mistakes in vocabulary and grammar. Otherwise, learners with incorrect pronunciation will not be understood even if their grammar and vocabulary are 
impressive. Furthermore, Buss (2015), Breitkreutz et.al. (2001), Foote et.al. (2011), Hismanoglu (2006), Martin (2015), Moeijito (2015), Setter \&Jenkins (2005) and Ustunbas (2018) believed that pronunciation plays an important role in a foreign language education.

\subsection{Goal of Teaching and Learning English Pronunciation}

According to Kenworthy (1987), Morley (1991), and Timmis (2002), it is necessary to provide an appropriate goal for pronunciation teaching based on the learners' needs. According to Kenworthy (1987, p. 13), intelligibility is "being understood by a listener at given time in a given situation". Likewise, Levis (2005, p. 370) states that intelligibility principle "holds that learners simply need to be understandable"while nativeness principle " holds that it is both possible and desirable to achieve native-like pronunciation in a foreign language".

In recent years, there has been an increasing amount of literature on the goal of learning English pronunciation. Studies conducted by Timmis (2002), Simon and Taverniers (2011), and Tergujef (2013) have found that many students perceive native-like pronunciation as their ideal goal, whilst lots of research has found that native-like pronunciation is no longer considered an appropriate goal for language learners to attain (Field, 2005; Morley, 1991; Jenkins, 2000; Walker, 2010). More importantly, native-like pronunciation is regarded as an unrealistic burden for both teachers and students (Cook, 2002; Derwing \& Munro, 2005; Levis, 2005), whereas intelligibility is identified as the dominant goal of learning (Alghazo, 2015; Breitkreutz et.al.,2001; Buss, 2015; Celce-Murcia et.al., 2010; Field,2005; Foote et.al., 2011; Jenkins, 2000 and Vu, 2016). In relation to Vietnamese context, Cunningham (1998) also concludes that Vietnamese is a tonal language; therefore, native-like pronunciation is not a realistic goal for Vietnamese learners.

\subsection{English as Lingua Franca Model}

English as a Lingua Franca (ELF hereafter) is a way to refer to communication in English between speakers whose first languages are different (Jenkins, 2009). ELF can occur among native English speakers, but in most cases it refers to the interaction between people who share neither a common mother tongue nor a common national culture, and between those who regard English as an additional language (Jenkins, 2009). More importantly, Scovel (1969) and Krashen (1973) suggest that learners possibly pronounce as native speakers in their childhood whereas the level of native-like pronunciation cannot be reached by adults.

\section{RESEARCH QUESTIONS}

The study was conducted to answer the two research questions as follows:

Research question 1: What are high school students' beliefs about the role and goal of pronunciation in EFL classrooms in Binh Phuoc?

Research question 2: To what extent do the students agree or disagree with the beliefs regarding the goal and role of pronunciation?

\section{RESEARCH METHOD}

This study was carried out by employing the quantitative approach in which the data were collected by mean of questionnaire so as to understand students' beliefs about the role and goal of learning pronunciation in EFL classrooms.

\subsection{Participants}

The study was carried out simultaneously at four high schools in Binh Phuoc province: Quang Trung, Binh Long, Hung Vuong, and Dong Xoai. The participants in this study consisted of 249 students in total. They are the $10^{\text {th }}, 11^{\text {th }}$ and $12^{\text {th }}$ graders from the four high schools and their English proficiency is not at the same degree (see Table 1 below).To collect the data, the questionnaire wasdirectly delivered to all students. 
High School Students' Beliefs about the Role and Goal of Learning Pronunciation in EFL Classrooms in Binh Phuoc Province

Table1: The distribution for 249 respondents to the questionnaire

\begin{tabular}{|l|l|l|l|}
\hline & & \multicolumn{2}{|c|}{$\mathbf{~}=\mathbf{2 4 9}$} \\
\hline \multirow{4}{*}{ Gender } & & \multicolumn{1}{|c|}{ F \% } \\
\hline \multirow{5}{*}{ School } & Male & 77 & $30.92 \%$ \\
\cline { 2 - 4 } & Female & 172 & $69.08 \%$ \\
\cline { 2 - 4 } & Quang Trung & 73 & $29.32 \%$ \\
\cline { 2 - 4 } & Binh Long & 84 & $33.73 \%$ \\
\cline { 2 - 4 } & Hung Vuong & 45 & $18.07 \%$ \\
\cline { 2 - 4 } & Dong Xoai & 47 & $18.88 \%$ \\
\hline \multirow{5}{*}{ Grade } & 10 & 91 & $36.55 \%$ \\
\cline { 2 - 4 } & 11 & 96 & $38.55 \%$ \\
\cline { 2 - 4 } & 12 & 62 & $24.89 \%$ \\
\hline
\end{tabular}

\subsection{Instrument}

Questionnaire was employed to collect data in this study, and was designed in both Vietnamese and English following Five-point Likert scale format $(1=$ strongly disagree, $2=$ disagree, $3=$ neither agree nor disagree, $4=$ agree, $5=$ strongly agree). The questionnaire consists of two sections. In the first one, three questions are used to query the personal information of the respondents including genders, schools and ages. The participants were asked to complete their demographics by putting a tick in the relevant boxes that suited their cases. The second section focuses on the participants' beliefs about the role and goal of English pronunciation (EP- here after). In order to ensure the validity and reliability of the questionnaire, the researcher designed the questionnaire first in English and then translated into Vietnamese to make sure that the participants understood all the items, and completed it faster, just in case, some participants were not proficient in English.

Items in student questionnaire were adapted from the studies of Alghazo, (2015), Breitkreutz et.al. (2001), Buss (2015), Martin (2015), Moedjito (2016), and Ustunbas, (2018) because the author has realized that the questionnaires employed in these studies have had most of the features in common with the related literature that the thesis author has reviewed. In other words, they could suit the context of this current research.

The reliability of the questionnaire was also qualitatively computed by SPSS (24.0) to produce Cronbach's Alpha Coefficients. After three times of reliability statistics running, the two items were excluded from the questionnaire (see Table 2).

Table2: Reliability statistics for the student questionnaire

\begin{tabular}{|l|l|l|l|l|l|}
\hline Part & Times of running & Cronbach's Alpha & No. of Items & Total correlation & Items excluded \\
\hline \multirow{4}{*}{ II } & 1 & .566 & 8 & -.086 & EP7 \\
\cline { 2 - 6 } & 2 & .673 & 7 & .151 & EP6 \\
\cline { 2 - 6 } & 3 & $\mathbf{. 7 3 4}$ & 6 & $>.300$ & 0 \\
\hline
\end{tabular}

\subsection{Data Collection and Analysis Procedure}

The researcher contacted the four high school principals in Binh Phuoc province, and asked for their permission to conduct the research. When the four principals allowed the research to be conducted at their schools, the researcher was introduced to the schools' teachers. Hard copies of the questionnaire were directly distributed to participants during the class time in about thirty minutes. The author waited to collect the questionnaire copies and to answer the respondents' queries as well. This procedure was done to make sure that all copies of the questionnaire were responded correctly and fully.

In this study, the software Statistical Package for the Social Sciences (SPSS) version 24.0 was used to analyze the data obtained from 249 completed copies of the questionnaire. The Microsoft Excel 2016 was used to produce the percentage of the responses for each item as well as for general attitude. The non-parametric Wilcoxon Signed Ranks test was employed to compare students' consideration for the goal of learning pronunciation. 
High School Students' Beliefs about the Role and Goal of Learning Pronunciation in EFL Classrooms in Binh Phuoc Province

\section{FINDINGS}

\subsection{High School Students' Beliefs about the Role and Goal of Learning English Pronunciation in EFL Classrooms in Binh Phuoc Province}

Table 3 shows the results the students' beliefs about the role of learning English pronunciation. The data in terms of percentage were presented in a descending order as follows: (Mean \& S.D are presented for reference only).

Table3: Students' beliefs about the role of learning English pronunciation $(n=249)$

\begin{tabular}{|c|c|c|c|c|c|c|c|c|}
\hline No & Items & $\begin{array}{l}\text { Strongly } \\
\text { disagree }\end{array}$ & Disagree & $\begin{array}{l}\text { Neither Agree } \\
\text { nor disagree }\end{array}$ & Agree & $\begin{array}{l}\text { Strongly } \\
\text { Agree }\end{array}$ & Mean & S.D \\
\hline \multirow[t]{2}{*}{ EP1 } & $\begin{array}{l}\text { Learning } \\
\text { pronunciation is }\end{array}$ & \multicolumn{2}{|l|}{$\begin{array}{l}1 \\
(0.40 \%)\end{array}$} & \multirow[t]{2}{*}{$\begin{array}{l}5 \\
(2.01 \%)\end{array}$} & \multicolumn{2}{|c|}{$\begin{array}{l}243 \\
(97.59 \%)\end{array}$} & \multirow[t]{2}{*}{4.73} & \multirow[t]{2}{*}{.54} \\
\hline & $\begin{array}{l}\text { important in } \\
\text { learning English. }\end{array}$ & $\begin{array}{l}1 \\
(0.40 \%)\end{array}$ & $\begin{array}{l}0 \\
(0 \%)\end{array}$ & & $\begin{array}{l}54 \\
(21.69 \%)\end{array}$ & $\begin{array}{l}189 \\
(75.90 \%)\end{array}$ & & \\
\hline \multirow[t]{2}{*}{ EP3 } & $\begin{array}{l}\text { A } r \text { good } \\
\text { pronunciation in }\end{array}$ & \multicolumn{2}{|l|}{$\begin{array}{l}2 \\
(0.80 \%)\end{array}$} & \multirow[t]{2}{*}{$\begin{array}{l}7 \\
(2.81 \%)\end{array}$} & \multicolumn{2}{|l|}{$\begin{array}{l}240 \\
(96.39)\end{array}$} & \multirow[t]{2}{*}{4.57} & \multirow[t]{2}{*}{.61} \\
\hline & 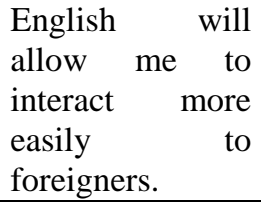 & $\begin{array}{l}1 \\
(0.40 \%)\end{array}$ & $\begin{array}{l}1 \\
(0.40 \%)\end{array}$ & & $\begin{array}{l}85 \\
(34.14 \%)\end{array}$ & $\begin{array}{l}155 \\
(62.25 \%)\end{array}$ & & \\
\hline \multirow[t]{2}{*}{ EP2 } & \multirow{2}{*}{$\begin{array}{l}\text { Acquiring proper } \\
\text { pronunciation in } \\
\text { English is } \\
\text { important to me. }\end{array}$} & \multicolumn{2}{|l|}{$\begin{array}{l}8 \\
(3.21 \%) \\
\end{array}$} & \multirow[t]{2}{*}{$\begin{array}{l}15 \\
(6.02 \%)\end{array}$} & \multicolumn{2}{|l|}{$\begin{array}{l}226 \\
(90.76)\end{array}$} & \multirow[t]{2}{*}{4.47} & \multirow[t]{2}{*}{.75} \\
\hline & & $\begin{array}{l}0 \\
(0 \%)\end{array}$ & $\begin{array}{l}8 \\
(3.21 \%)\end{array}$ & & $\begin{array}{l}77 \\
(30.92 \%)\end{array}$ & $\begin{array}{l}149 \\
(59.84 \%)\end{array}$ & & \\
\hline
\end{tabular}

As shown in Table 2, $97.59 \%$ (243 out of 249) of the student participants responded that they either agreed or strongly agreed with the statement that "Learning pronunciation is important in learning English" (Item EP1, M=4.73, SD=.54).In addition, 96.39\% of them agreed that a good pronunciation in English would allow them to interact more easily to foreigners (Item EP3, M=4.57, SD=.612). Furthermore, $90.76 \%$ of the students acknowledged that it was very important to acquire proper pronunciation (Item EP2, M=4.47, SD=.75). In brief, Pronunciation has been considered a deciding factor helping learners to be successful in learning English.

Table 4 shows the results of the students' beliefs about the goal of learning English pronunciation. The data in terms of percentage were presented in descending order as follows:

Table4: Students' beliefs about the goal of learning English pronunciation ( $n=249)$

\begin{tabular}{|c|c|c|c|c|c|c|c|c|}
\hline No & Items & $\begin{array}{l}\text { Strongly } \\
\text { disagree }\end{array}$ & Disagree & $\begin{array}{l}\text { Neither Agree } \\
\text { nor disagree }\end{array}$ & Agree & $\begin{array}{l}\text { Strongly } \\
\text { Agree }\end{array}$ & Mean & S.D \\
\hline \multirow[b]{2}{*}{ EP4 } & $\begin{array}{l}\text { I would like to } \\
\text { sound clear enough }\end{array}$ & \multicolumn{2}{|l|}{$\begin{array}{l}4 \\
(1.61 \%) \\
\end{array}$} & \multirow{2}{*}{$\begin{array}{l}18 \\
(17.23 \%)\end{array}$} & \multicolumn{2}{|l|}{$\begin{array}{l}227 \\
(91.16)\end{array}$} & \multirow[b]{2}{*}{4.33} & \multirow[b]{2}{*}{.72} \\
\hline & $\begin{array}{lr}\text { to be } & \text { easily } \\
\text { understood } & \text { by } \\
\text { foreigners. } & \\
\end{array}$ & $\begin{array}{l}2 \\
(0.80 \%)\end{array}$ & $\begin{array}{l}2 \\
(0.80 \%)\end{array}$ & & $\begin{array}{l}116 \\
(46.59 \%)\end{array}$ & $\begin{array}{l}111 \\
(44.58)\end{array}$ & & \\
\hline \multirow[b]{2}{*}{ EP8 } & $\begin{array}{l}\text { I try hard to } \\
\text { improve }\end{array}$ & \multicolumn{2}{|l|}{$\begin{array}{l}7 \\
(2.81 \%)\end{array}$} & \multirow[b]{2}{*}{$\begin{array}{l}29 \\
(11.65 \%)\end{array}$} & \multicolumn{2}{|l|}{$\begin{array}{l}213 \\
(85.54 \%)\end{array}$} & \multirow[b]{2}{*}{4.28} & \multirow[b]{2}{*}{.79} \\
\hline & $\begin{array}{l}\text { English } \\
\text { pronunciation } \\
\text { because in today's } \\
\text { global society we } \\
\text { are expected to } \\
\text { pronounce words } \\
\text { accurately. }\end{array}$ & $\begin{array}{l}1 \\
(0.40 \%)\end{array}$ & $\begin{array}{l}6 \\
(2.41 \%)\end{array}$ & & $\begin{array}{l}99 \\
(39.76 \%)\end{array}$ & $\begin{array}{l}114 \\
(45.78 \%)\end{array}$ & & \\
\hline \multirow{2}{*}{ EP5 } & $\begin{array}{lr}\text { I } & \text { learn } \\
\text { pronunciation } & \text { to }\end{array}$ & \multicolumn{2}{|l|}{$\begin{array}{l}26 \\
(10.44 \%)\end{array}$} & \multirow{2}{*}{$\begin{array}{l}63 \\
(25.30 \%)\end{array}$} & $\begin{array}{l}160 \\
(64.26 \%)\end{array}$ & & \multirow{2}{*}{3.79} & \multirow{2}{*}{.98} \\
\hline & $\begin{array}{l}\text { sound like a native } \\
\text { speaker }\end{array}$ & $\begin{array}{l}3 \\
(1.20 \%)\end{array}$ & $\begin{array}{l}23 \\
(9.24 \%)\end{array}$ & & $\begin{array}{l}94 \\
(37.75 \%)\end{array}$ & $\begin{array}{l}66 \\
(26.51 \%)\end{array}$ & & \\
\hline
\end{tabular}


According to Table 4, most of the participants had their goal in learning English pronunciation. In particular, $91.16 \%$ of the participants wanted to sound clear enough to be easily understood by foreigners (item EP4, M=4.33, SD=.72). Similarly, 213 out of 249 students (85.54\%) set the goal when they learned English pronunciation that they needed to pronounce the words correctly in today's global society (item EP8, M=4.28, SD=.79). Furthermore, $64.26 \%$ of the questionnaire respondents either agreed or strongly agreed that they learned English to sound like a native speaker (item EP5, $\mathrm{M}=3.79, \mathrm{SD}=.98$ ). It can be concluded that almost all students established their goal when they started learning pronunciation.

According to the figures presented in Table 4, it is necessary to compare item EP4 and item EP5 in order to investigate the differences in students' pronunciation goal. In doing so, the non- parametric Wilcoxon Signed Ranks test was conducted based on students' responses to the items EP4 and EP5 and the results were displayed in Table 5below:

Table5: Wilcoxon Signed Ranks Test (EP4 vs. EP5)

\begin{tabular}{|l|l|l|}
\hline Item & Mean & Asymp. Sig. (2-tailed) \\
\hline $\begin{array}{l}\text { EP4: I would like to sound clear enough to be easily } \\
\text { understood by foreigners. }\end{array}$ & 4.33 & \multirow{2}{*}{.000} \\
\hline EP5: I learn pronunciation to sound like a native speaker. & 3.79 & \\
\hline
\end{tabular}

The significance coefficient, presented in Table 5, produced from the non-parametric Wilcoxon Signed Ranks test was $p=.000$ which was lower than $0.05(p<0.05)$. This means that the difference between the two items EP4 and EP5 was significant. Therefore, students in this study had a strong tendency towards the agreement that their goal of leaning pronunciation was intelligible. In other words, they wished to sound clear enough to be easily understood instead of sounding native-like when they communicated with foreigners.

\section{DISCUSSION}

According to results, the majority of the participants highly agreed that learning pronunciation was important in learning English. They truly recognized that good pronunciation could not only make students intelligible to everyone in oral communication, but also support them in improving their speaking and listening skills; what is more, students' confidence could be reinforced by correct pronunciation. These findings corroborate the findings of a great deal of the previous work in this field. For instance, Buss (2015), Breitkreutz et.al. (2001), Foote et.al. (2011), Hismanoglu (2006), Martin (2015), Moeijito (2015), Setter \&Jenkins (2005) and Ustunbas (2018) valued the importance of pronunciation for oral communicative competence and agreed that pronunciation instruction was often included in their class.

In this study, many students would like to sound clear enough to be easily understood by foreigners rather than to sound like native speakers. There are similarities between the attitudes expressed by participants in this study and those described by Alghazo, (2015), Breitkreutz et.al. (2001), Buss (2015), Celce-Murcia et.al. (2010), Field (2005), Foote et.al. (2011), Jenkins (2000) and Vu (2016) who agreed that students did not need more than a comfortably intelligible pronunciation. Furthermore, as concluded by Cunningham (1998), native-like pronunciation is not realistic goal for Vietnamese learners not only because Vietnamese is a tonal language, but also there is lack of chances for students to interact with native speakers. Hence, the use of English as a Lingua Franca (ELF) which has been given undivided attention to intelligibility is an ideal goal for pronunciation learning.

\section{CONCLUSION}

The present study was conducted to investigate the beliefs about the role and goal of learning pronunciation among high school students in EFL classrooms in Binh Phuoc province. Regarding the role and goal of pronunciation in learning English, the results of this investigation have shown that students valued the importance of pronunciation for oral communicative competence. Furthermore, they highly agreed that good pronunciation could not only make students' speech intelligible but also enhance their confidence, since pronunciation has been vitally taught in classrooms. Additionally, the students showed their views on the goal of learning pronunciation that intelligible pronunciation was believed to be more realistic for them to achieve than native-like pronunciation. 


\section{LIMITATION AND RECOMMENDATION}

This study is limited to examining students' beliefs about the role and goal of pronunciation. It is recommended that future research should explore the teachers' beliefs in the same issues and make a comparison between high school students' and teachers' beliefs. Moreover, the effectiveness of current practices of teaching and learning pronunciation in EFL classroom should be taken into account. It is noteworthy that more research instruments including interviews, observations, Independent Samplet Test, etc.should be employed to gain more valid and reliable results.

\section{REFERENCES}

[1] Alghazo, M. S. (2015). Advanced EFL learners' beliefs about pronunciation teaching. International Education Studies, 8, 63-76.

[2] Baker, A. (2014). Exploring teachers' knowledge of second language pronunciation techniques: teacher cognitions, observed classroom practice, and student perceptions. TESOL Quarterly, 48(1), 136-163.

[3] Burns,A.(2006). Intergrating research and professional development on pronunciation teaching in a national adult ESL program. TESL Reporter, 39, 34-41.

[4] Buss, L.(2015). Beliefs and practices of Brazilian EFL teachers regarding pronunciation. Language Teaching Research, 20(5), 1-19.

[5] Breitkreutz, J. A., Derwing, T. M., \& Rossiter, M. (2001). Pronunciation teaching practices in Canada. TESL Canada Journal, 19(1), 51-61.

[6] Celce-Murcia, M., Brinton, D. M., Goodwin, J. M., \& Griner, B. (2010). Teachingpronunciation: a course book and reference guide. New York: Cambridge Unversity Press.

[7] Cook, V. (2002). Language teaching methodology and the L2 user perspective. InV. Cook (Ed.), Portraits of the L2 users. Sydney: Multilingual Matters LTD.

[8] Cunningham, F. (1998). Improving adults ESL learners' pronunciation skills.Eric Digests, 1-8. ED427553

[9] Derwing, T. M., \& Munro, M. J. (2005). Second language accent and pronunciation teaching: A researchbased approach . TESOL Quarterly, 39, 379-397.

[10] Field, J. (2005). Intelligibility and the listener: The role of lexical stress. TESOL Quarterly, 39, 399-423.

[11] Foote, J. A., Holtby, A. K., \& Derwing, T. M. (2011). Survey of the teaching of pronunciation in adults ESL programs in Canada, 2010. TESL Canada Journal, 29(1), 1-22.

[12] Hismanoglu, M. (2006). Current perspective on pronunciation learning and teaching. Journal of Language and Linguistic Studies, 87-100.

[13] Jenkins, J. (2000). The phonology of English as an international language. Oxford: Oxford University Press.

[14] Jenkins, J. (2009). English as a Lingua Franca: interpretations and attitudes. World Englishes, 28(2), 200-207.

[15] Levis, J. (2005). Changing the contexts and shifting paradigms in pronunciation teaching. TESOL Quarterly, 39(3), 369-377.

[16] Martin, C. (2015). Students' and teachers' perception of the role of pronunciation in the EFL classroom (Unpublished Master Dissertation Awards). Canterbury Christ Church University.

[17] Moedjito. (2016). The Teaching of English Pronunciation: Perceptions of Indonesian School Teachers and University Students. English Language Teaching, 9(6), 30-41.

[18] Morley, J. (1991). The pronunciation component in teaching english to speakers of other languages. TESOL Quarterly, 25(3), 481-519.

[19] Kenworthy, J. (1987). Teaching English pronunciation. Harlow: Longman. Krashen, S. (1973). Lateralization, language learning, and the critical period: Some new evidence. Language Learning, 23(1), 63-74.

[20] Setter, J., \& Jenkins, J. (2005). Pronunciation. Language Teaching, 38(1), 1-17.

[21] Scovel, T. (1969). Foreign accents, language acquisition and cerebral dominance. Language Learning, 19(3), 245-254.

[22] Simon, E., \& Taverniers, M. (2011). Advanced efl learners' beliefs about language learning and teaching: A comparision between grammar, pronunciation, and vocabulary. English Studies, 92(8), 896-922.

[23] Timmis, I. (2002). Native - Speaker norms and international English: a classroom view. English Language Taeching Journal,56(3), 240-249.

[24] Tergujeff, E. (2013). Learners' perspective on English pronunciation teaching in an EFL context. Research in Language, 11(1), 81-95. 
High School Students' Beliefs about the Role and Goal of Learning Pronunciation in EFL Classrooms in Binh Phuoc Province

[25] Truong, N. N. T. (2018). The extent to which the Vietnamese teachers' perspectives on English pronunciation education correlate with those of the Vietnamese learners (Published Master Thesis). Radboud University Nijmegen.

[26] Ustunbas, U. (2018). Does pronunciation instruction make any sense? EFL learners and teachers' beliefs. International Journal of Curriculum and Instruction, 10(1), 71 -84.

[27] Vu, Y. H. (2016 ). Exploring English Pronuncaition teaching in Vietnam: Time for a new approach? (Unpublished Master's Thesis). Macquarie University.

[28] Walker, R. (2010). Teaching the pronunciation of English as lingua franca. Oxford, England: Oxford University Press.

\section{AUTHORS' BIOGRAPHY}

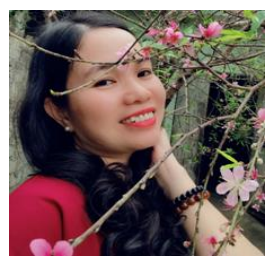

Ms. Le Thanh Huyen is an MA student majoring in English language at Ho Chi Minh City University of Technology, Vietnam. Her academic areas of interests lie in pronunciation, phonetics, phonology and EFL teaching methodology.

Citation: Saleh Batais. High School Students' Beliefs about the Role and Goal of Learning Pronunciation in EFL Classrooms in Binh Phuoc Province. "International Journal on Studies in English Language and Literature (IJSELL), vol 7, no.7, 2019, pp. 37-43. doi: http://dx.doi.org/10.20431/2347-3134. 0707005.

Copyright: () 2019 Authors. This is an open-access article distributed under the terms of the Creative Commons Attribution License, which permits unrestricted use, distribution, and reproduction in any medium, provided the original author and source are credited. 